DOI: https://doi.org/10.32838/2523-4803/69-5-43

УДК 338.246 .2

\title{
Шиатакова О.Л.
}

аспірантка кафедри фінансів, обліку і маркетингу,

ДВНЗ «Придніпровська державна академія будівництва та архітектури»

\section{Shpatakova Oksana}

Prydniprovs'ka State Academy of Civil Engineering and Architecture

\section{ДОСЛІДЖЕННЯ НЕГАТИВНОГО ВПЛИВУ БУДІВЕЛЬНОГО ПІДПРИЕМСТВА НА НАВКОЛИШНЕ ПРИРОДНЕ СЕРЕДОВИЩЕ}

\begin{abstract}
У статті здійснено дослідження, націлене на методичне забезпечення та практичну оцінку негативного впливу досліджуваних будівельних підприємств Дніпропетровської області на навколишнє природне середовище. Розроблено авторське методичне забезпечення оиінки негативного впливу досліджуваних будівельних підприємств на навколишнє природне середовище, щцо передбачає п'ять етапів. Наукова новизна запропонованої методики полягає у тому, шэо в ній уперше на основі нормативного та порівняльного методів визначено методичне забезпечення для підприємств будівельної галузі, тоді як здебільшого оцінка здійснюється відповідно до методик розрахунку певних оціночних показників. Керуючись положеннями авторської методики, проведено оцінку досліджуваної проблематики на прикладі двох суб' єктів будівельної галузі. Встановлено, щчо рівень негативного впливу циих суб'єктів будівельної галузі на навколишнє природне середовище був нижчим нормативного за основними напрямами, управління відходами було ефективним.

Ключові слова: негативний вплив, екологізація, будівельна галузь, навколишнє природне середовище, викиди, будівельна продукція, нормативні дані, житлові території.
\end{abstract}

Постановка проблеми. Будівельна галузь є сферою потужного антропогенного впливу на навколишнє природне середовище. Дія на це середовище відбувається як у процесі здійснення будівництва, оскільки для його забезпечення потрібна велика кількість будівельних матеріалів, сировини, водних, енергетичних, інших ресурсів, так і під час експлуатації житлових, нежитлових об'єктів, інженерної інфраструктури тощо. Кожний етап будівництва потребує відповідної комплексної оцінки, яку необхідно здійснювати на професійному рівні, оскільки неврахування впливу будівельної діяльності може нанести шкоду навколишньому природному середовищу, стати причиною великого податкового навантаження для підприємства у виглядів штрафів за порушення встановленої законодавством України гранично допустимої концентрації викидів. Зважаючи на зазначене, дослідження проблеми методичного забезпечення та практичної оцінки негативного впливу будівельних підприємств (на прикладі суб'єктів Дніпропетровської обл.) на навколишнє природне середовище $є$ актуальним.

Аналіз останніх досліджень і публікацій. Проблемам методичного забезпечення оцінки негативного впливу підприємств на навколишнє природне середовище присвячено наукові праці В. Хобти, О. Руднєвої [6], М. Свєтунькова, В. Смолькіна [4], О. Латишевої [3], аналітичні та звітні матеріали за вказаною проблематикою. Незважаючи на існування наукових досліджень за даним напрямом, є потреба методичного забезпечення оцінки, яка б ураховувала особливості функціонування підприємств будівельної галузі.

Формулювання цілей статті. Метою дослідження $€$ методичне забезпечення та практична оцінка негативного впливу досліджуваних будівельних підприємств Дніпропетровської обл. на навколишнє природне середовище. Для досягнення вказаної мети встановлено такі завдання:

1) створення методичного забезпечення оцінки негативного впливу досліджуваних будівельних підприємств на навколишнє природне середовище;

2) здійснення оцінки негативного впливу досліджуваних будівельних підприємств Дніпропетровської обл. на навколишнє природне середовище.

Виклад основного матеріалу. Для вивчення стратегічного управління екологізацією необхідно встановити фактичний рівень впливу цих підприємств на навколишнє природне середовище регіону впродовж останніх років (2015-2017рр.). Здійснення такого виду оцінки потребує визначення відповідного методичного забезпечення. На нашу думку, оцінка зазначеної проблематики повинна бути здійснена із застосуванням методу порівняльного аналізу, нормативного методу. На рис. 1 представлено авторську методику оцінки негативного впливу досліджуваних будівельних підприємств на навколишнє природне середовище, яка передбачає п'ять етапів. У складі основних оціночних 


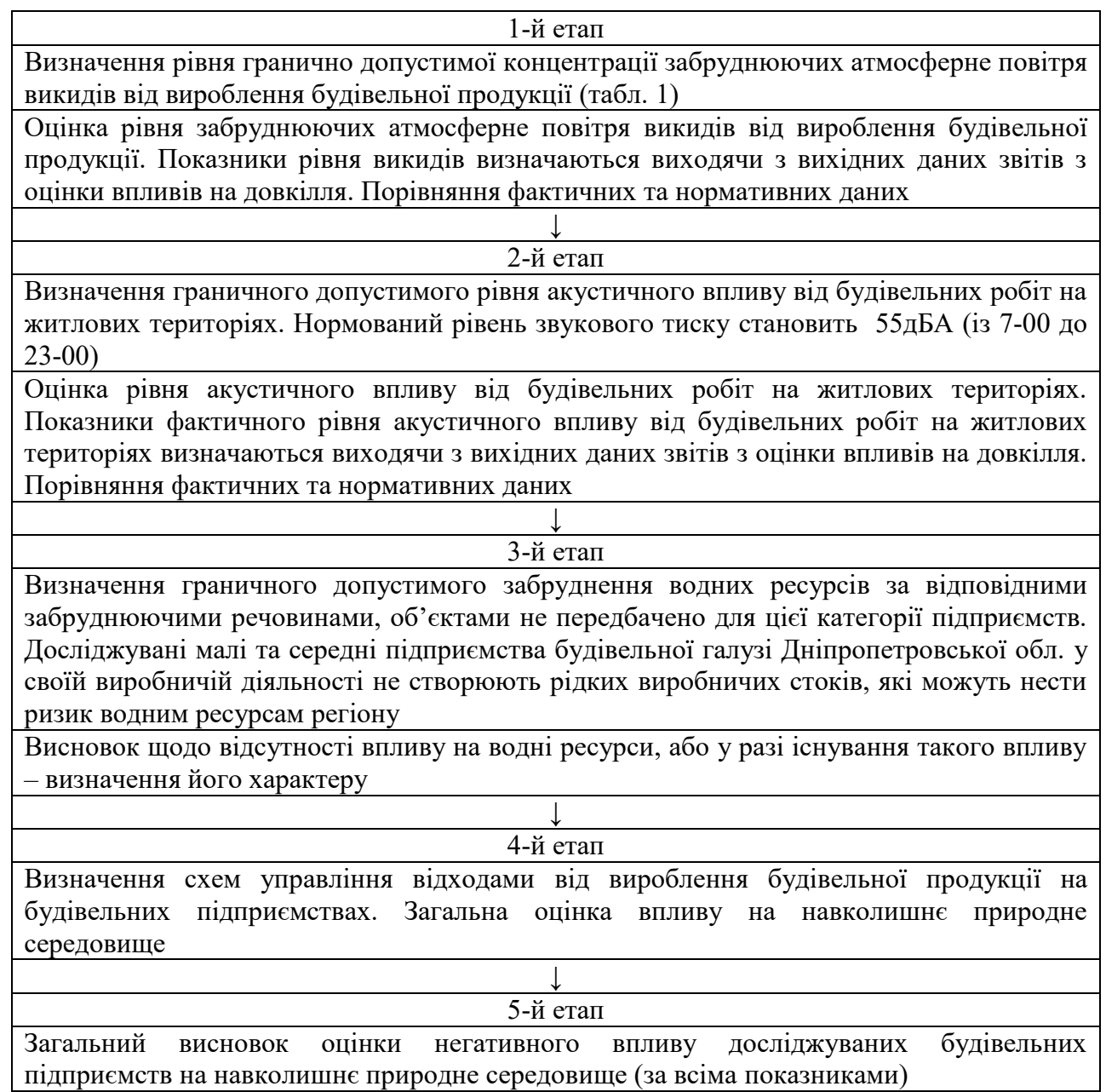

Рис. 1. Методика оцінки негативного впливу досліджуваних будівельних підприсмств на навколишне природне середовище

Джерело: авторська розробка

показників використано такі, що найбільшою мірою характеризують негативний вплив на навколишнє природне середовище від діяльності будівельних підприємств. Наукова новизна запропонованої методики полягає у тому, що в ній уперше на основі нормативного та порівняльного методів визначено методичне забезпечення для підприємств будівельної галузі, тоді як здебільшого оцінка здійснюється відповідно до методик розрахунку певних оціночних показників. Указане методичне забезпечення може бути використано для розвитку методичної бази аналізу, практичних цілей дослідження.

Авторською методикою оцінки (рис. 1) передбачено визначення рівня гранично допустимої концентрації забруднюючих атмосферне повітря викидів від вироблення будівельної продукції (табл. 1).

Аналіз стану стратегічного управління екологізацією будівельного виробництва здійснюється на прикладі двох будівельних підприємств Дніпропетровської області, які декларують та здійснюють упровадження екологічних стратегій розвитку. У складі вказаних досліджуваних підприємств виділено ПрАТ «НВО
«Созидатель» (м. Дніпро) [2], ПрАТ «Металургпромжитлобуд» (м. Кам'янське) [5].

У табл. 2 представлено оцінку негативного впливу ПрАТ «НВО «Созидатель» (м. Дніпро) на навколишне природне середовище за період 2015-2017 рр.

Досліджуване підприємство займається будівництвом житлових та нежитлових об’єктів у м. Дніпро. Як свідчать результати табл. 2, фактичний рівень впливу забруднюючих атмосферне повітря викидів від вироблення будівельної продукції впродовж досліджуваного періоду 2015-2017 рр. був меншим нормативного за всіма видами забруднюючих речовин. Слід відзначити, що фактичний рівень від граничного нормативу на рік за цими речовинами за 2015-2017 pр. мав тенденцію до зростання, а саме: у 2016 р. порівняно з 2015 р. він зріс з 0,3\% до 9,5\% (найбільше зростання шкідливих викидів відзначалося за фтористим воднем (на 9,3\%), титану діоксидом (на 6,6\%), погано розчинними фторидами (на 5,5\%)); у 2017 р. порівняно з 2016 р. збільшився 3 0,4\% до 5,7\% (найбільше зростання шкідливих викидів відзначалося за фтористим воднем (на 4,8\%), титану діоксидом (на 8,6\%). Відповідно, хоча найбільший 
Рівень гранично допустимої концентрації забруднюючих атмосферне повітря викидів від вироблення будівельної продукції

\begin{tabular}{|c|c|c|}
\hline № п//ா & $\begin{array}{c}\text { Назва виду забруднюючих речовин, які виникають } \\
\text { від вироблення будівельної продукції }\end{array}$ & 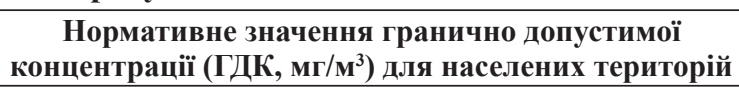 \\
\hline 1 & Оксиди азоту & $0,5 \mathrm{M \Gamma} / \mathrm{M}^{3}$ \\
\hline 2 & ВСТЧ & $0,5 \mathrm{M} \Gamma / \mathrm{M}^{3}$ \\
\hline 3 & Оксид вуглецю & $5 \mathrm{M} \Gamma / \mathrm{M}^{3}$ \\
\hline 4 & Сірки діоксин & $0,5 \mathrm{M} \Gamma / \mathrm{M}^{3}$ \\
\hline 5 & Бенз(а)пірени & 0,1 мкг $/ 100 \mathrm{~m}^{3}$ \\
\hline 6 & НМЛОС & $0,2 \mathrm{M \Gamma} / \mathrm{M}^{3}$ \\
\hline 7 & Фтористий водень & $0,02 \mathrm{M \Gamma} / \mathrm{M}^{3}$ \\
\hline 8 & Залізо і його сполуки & $0,04 \mathrm{M \Gamma} / \mathrm{M}^{3}$ \\
\hline 9 & ПРФ & $0,2 \mathrm{M} \Gamma / \mathrm{M}^{3}$ \\
\hline 10 & Манган і його сполуки & $0,001 \mathrm{M \Gamma} / \mathrm{M}^{3}$ \\
\hline 11 & Титану діоксид & $0,5 \mathrm{M} \Gamma / \mathrm{M}^{3}$ \\
\hline 12 & ЛРФ & $0,03 \mathrm{Mr} / \mathrm{M}^{3}$ \\
\hline
\end{tabular}

Де: ВСТЧ - викиди суспендованих твердих частинок; НМЛОС - неметанові леткі органічні сполуки; ПРФ - погано розчинні фториди; ЛРФ - легко розчинні фториди.

Джерело: складено автором за матеріалами [1]

рівень атмосферних викидів від будівельної діяльності підприємства за шкідливими речовинами і не перебільшив у 2017 р. рівня 28,2\%, спостерігається поступове зростання негативного впливу.

Відповідно до результатів табл. 2, рівень акустичного впливу від будівельних робіт підприємства на житлових територіях упродовж досліджуваного періоду 2015-2017 рр. був меншим нормативного, але також зростав із 27,6\% до 31,5\% від норми 55дБА. Встановлено, що забруднення водних ресурсів за відповідними забруднюючими речовинами, об'єктами будівництва вказаного підприємства відсутнє. Управління всіма видами відходів від вироблення будівельної продукції на будівельному підприємстві передбачає їх регулярне вивезення завдяки співпраці зі спеціалізованою компанією на умовах аутсорсингу (договірні відносини).

У цілому можна констатувати, що рівень негативного впливу ПрАТ «НВО «Созидатель» (м. Дніпро) на навколишнє природне середовище за період 2015-2017 рр. характеризується як такий, що нижче нормативного за основними напрямами; управління відходами було ефективним, не створювало загроз для довкілля. Щодо управління відходами, то слід відзначити, що підприємство не здійснює його на власних потужностях, не передбачено впровадження інноваційних за основними напрямами, управління відходами було ефективним, не створювало загроз для довкілля. Щодо управління відходами, то слід відзначити, що підприємство не здійснює його на власних потужностях, не передбачено впровадження інноваційних заходів вторинної переробки певних видів відходів.

У табл. 3 наведено оцінку негативного впливу ПрАТ «Металургпромжитлобуд» (м. Кам'янське) на навколишнє природне середовище за період 2015-2017 pp.

Указане підприємство належить до категорії малих підприємств, здійснює будівництво, ремонт житлової та нежитлової інфраструктури. Незважаючи на категорію, до якої віднесено підприємство, на управлінському рівні здійснюється оцінка негативної дії будівельної діяльності на навколишнє природне середовище. Відповідно до результатів розрахунків, можемо відзначити, що фактичний рівень впливу забруднюючих атмосферне повітря викидів від вироблення будівельної продукції впродовж досліджуваного періоду 2015-2017 рр. був меншим нормативного за всіма видами забруднюючих речовин. При цьому впродовж досліджуваного періоду 2015-2017 рр., як і у випадку попереднього підприємства, відбувається зростання викидів таких шкідливих речовин, а саме: у 2016 р. зростання становило від 0,2\% до 5,5\% (найбільше збільшення викидів відбулося за бенз(а)піренами (6,9\%), манганом і його сполуками (5,5\%)); у 2017 р зріст дорівнював від 1\% до 3,4\% (найбільше збільшення викидів було за бенз(а)піренами (6\%)).

Згідно з даними табл. 3, рівень акустичного впливу від будівельних робіт підприємства на житлових територіях упродовж досліджуваного періоду 2015-2017 pp. був меншим нормативного і демонстрував тенденцію до скорочення (з 18,5\% до 16,8\% від норми 55дБА). Вказане пов'язане 3 використанням нових інструментів, придбаних раніше. Доведено, що забруднення водних ресурсів за відповідними забруднюючими речовинами, об'єктами будівництва вказаного підприємства відсутнє. Процес управління всіма видами відходів від вироблення будівельної продукції на будівельному підприємстві передбачає їх регулярне вивезення завдяки співпраці зі спеціалізованими компаніями (договірні відносини).

Необхідно зробити висновок, що рівень негативного впливу ПрАТ «Металургпромжитлобуд» (м. Кам'янське) на навколишнє природне середовище за період 2015-2017 рр. був нижчим нормативного за основними напрямами; управління відходами було ефективним, не створювало загроз для довкілля. Сто- 
Оцінка негативного впливу ПрАТ «НВО «Созидатель» (м. Дніпро) на навколишнє природне середовище за період 2015-2017 рр.

\begin{tabular}{|c|c|c|c|c|c|c|c|c|}
\hline \multirow[b]{2}{*}{$\begin{array}{l}\text { № } \\
\text { пI/II }\end{array}$} & \multirow[b]{2}{*}{$\begin{array}{c}\text { Оціночні } \\
\text { показники }\end{array}$} & \multirow[b]{2}{*}{$\begin{array}{c}\text { Нормативні } \\
\text { значення }\end{array}$} & \multicolumn{6}{|c|}{ Фактичні звітні значення } \\
\hline & & & 2015 p. & \begin{tabular}{|c|}
$\begin{array}{c}\% \text { від } \\
\text { ГН на } \\
\text { рік }\end{array}$ \\
\end{tabular} & 2016 p. & $\begin{array}{c}\% \text { \% від } \\
\text { ГН на } \\
\text { рік }\end{array}$ & 2017 p. & $\begin{array}{c}\text { \% від } \\
\text { ГН на } \\
\text { рік }\end{array}$ \\
\hline I & PB ATM & & $11,748526 \mathrm{~T}$ & \begin{tabular}{|c|} 
від 8 \\
до $13 \%$
\end{tabular} & $12,294486 \mathrm{~T}$ & $\begin{array}{c}\text { від } \\
8,3 \text { до } \\
22,5 \%\end{array}$ & $13,305713 \mathrm{~T}$ & $\begin{array}{c}\text { від } \\
8,7 \text { до } \\
28,2 \%\end{array}$ \\
\hline 1.1 & Оксиди азоту & 0,5 мг/м3 & $1,578 \mathrm{~T}$ & 9 & $1,621 \mathrm{~T}$ & 9,2 & $1,77 \mathrm{~T}$ & 10,1 \\
\hline 1.2 & \begin{tabular}{|l|} 
Викиди \\
суспендованих \\
твердих частинок
\end{tabular} & $0,5 \mathrm{M} \Gamma / \mathrm{M} 3$ & $0,668 \mathrm{~T}$ & 12 & $0,69 \mathrm{~T}$ & 12,4 & $0,72 \mathrm{~T}$ & 12,9 \\
\hline 1.3 & Оксид вуглецю & $5 \mathrm{мг} / \mathrm{M} 3$ & $6,818 \mathrm{~T}$ & 8 & $7,1 \mathrm{~T}$ & 8,3 & $7,4 \mathrm{~T}$ & 8,7 \\
\hline 1.4 & Сірки діоксин & 0,5 мг/м3 & $0,873 \mathrm{~T}$ & 12 & $0,95 \mathrm{~T}$ & 13,1 & $1,1 \mathrm{~T}$ & 15,1 \\
\hline 1.5 & Бенз(а)пірени & 0,1 мкг / 100 м3 & $0,0000111 \mathrm{~T}$ & 8 & $0,000012 \mathrm{~T}$ & 9,1 & $0,000016 \mathrm{~T}$ & 12,1 \\
\hline 1.6 & НМЛОС & $0,2 \mathrm{мг} / \mathrm{M} 3$ & $1,800 \mathrm{~T}$ & 9,5 & $1,92 \mathrm{~T}$ & 10,1 & $2,3 \mathrm{~T}$ & 12,1 \\
\hline 1.7 & \begin{tabular}{|l} 
Фтористий \\
водень
\end{tabular} & 0,02 мг/м3 & $0,001 \mathrm{~T}$ & 9 & $0,0014 \mathrm{~T}$ & 22,5 & $0,0017 \mathrm{~T}$ & 27,3 \\
\hline 1.8 & \begin{tabular}{|l|} 
Залізо і його \\
сполуки
\end{tabular} & 0,04 мг/м3 & $0,005 \mathrm{~T}$ & 8 & $0,0055 \mathrm{~T}$ & 8,1 & $0,0062 \mathrm{~T}$ & 9,2 \\
\hline 1.9 & ПРФ & 0,2 мг/м3 & $0,002 \mathrm{~T}$ & 12 & $0,0024 \mathrm{~T}$ & 17,5 & $0,0027 \mathrm{~T}$ & 19,7 \\
\hline 1.10 & \begin{tabular}{|l|}
$\begin{array}{l}\text { Манган і його } \\
\text { сполуки }\end{array}$ \\
\end{tabular} & $0,001 \mathrm{мг} / \mathrm{M} 3$ & $0,00041 \mathrm{~T}$ & 12 & $0,00045 \mathrm{~T}$ & 13,1 & $0,00053 \mathrm{~T}$ & 15,4 \\
\hline 1.11 & Титану діоксид & 0,5 мг/м3 & $0,00001 \mathrm{~T}$ & 13 & $0,000016 \mathrm{~T}$ & 19,6 & $0,000023 \mathrm{~T}$ & 28,2 \\
\hline 1.12 & ЛРФ & $0,03 \mathrm{мг} / \mathrm{M} 3$ & $0,003 \mathrm{~T}$ & 12 & $0,0036 \mathrm{~T}$ & 13,1 & $0,0044 \mathrm{~T}$ & 16,1 \\
\hline II & PA & 55 дБА & 15,2 дБА & 27,6 & 16,3 дБА & 29,6 & 17,4 дБА & 31,6 \\
\hline III & PB BP & & 0 & & 0 & & 0 & \\
\hline IV & Схема управління & В1дходами вІд н & роблення будіве & ої проду & укції на будівель & му підпр & Іємстві & \\
\hline 4.1 & BMM, T & & 3,8 & & 4,1 & & 4,3 & \\
\hline 4.2 & ВПММ, т & & 12,1 & & 13,5 & & 15 & \\
\hline 4.3 & ВБМ, т & & 47 & & 48,5 & & 50,2 & \\
\hline 4.4 & ВЛ, $\mathrm{T}$ & & 3,2 & & 3,9 & & 4,4 & \\
\hline & Разом відходи, т & & 66,1 & & 70 & & 73,9 & \\
\hline $\mathrm{V}$ & $\begin{array}{l}\text { Загальний } \\
\text { висновок щодо } \\
\text { негативного } \\
\text { впливу }\end{array}$ & & $\begin{array}{l}\text { Вплив } \\
\text { знаходиться } \\
\text { на рівні нижче } \\
\text { нормативного. } \\
\text { Управління } \\
\text { відходами } \\
\text { ефективне }\end{array}$ & & \begin{tabular}{|l} 
Вплив \\
знаходиться \\
на рівні нижче \\
нормативного. \\
Управління \\
відходами \\
ефективне
\end{tabular} & & \begin{tabular}{|l} 
Вплив \\
знаходиться \\
на рівні нижче \\
нормативного. \\
Управління \\
відходами \\
ефективне
\end{tabular} & \\
\hline
\end{tabular}

Де: ВMM - відходи металевого лому від монтажів конструкцій (відходи IV класу небезпеки) - управління передається на аутсорсинг спеціалізованій компанії (регулярне вивезення), т; ВПММ - відходи паливно-мастильних матеріалів (відходи IV класу небезпеки) - управління передається на аутсорсинг спеціалізованій компанії (регулярне вивезення), т; ВБМ - відходи будівельних матеріалів (відходи IV класу небезпеки) - управління передається на аутсорсинг спеціалізованій компанії (регулярне вивезення), т; ВЛ - відходи лісоматеріалів (відходи IV класу небезпеки) - управління передається на аутсорсинг спеціалізованій компанії (регулярне вивезення), т.

Джерело: розраховано за даними [2]

совно управління відходами можна відзначити відсутність інноваційності за вказаним напрямом, будівельне підприємством не впроваджує новітніх методів вторинної переробки певних видів відходів.

Висновки. Розроблено авторську методику оцінки негативного впливу досліджуваних будівельних підприємств на навколишнє природне середовище. Керуючись іiі положеннями, проведено оцінку досліджуваної проблематики на прикладі двох суб'єктів галузі Дніпропетровської обл. за 2015-2017 рр. Встановлено, що рівень негативного впливу цих суб'єктів буді- вельної галузі на навколишнє природне середовище був нижчим нормативного за основними напрямами, управління відходами було ефективним. Визначено, що всі досліджувані підприємства не впроваджували інноваційних аспектів управління екологізацією в рамках управління відходами будівельної діяльності. Можемо констатувати, що представлена методика дала змогу оцінити рівень негативного впливу зазначених суб'єктів будівельної галузі регіону впродовж указаного періоду, визначити загальну картину управління екологізацією. 
Оцінка негативного впливу ПрАТ «Металургпромжитлобуд» (м. Кам'янське) на навколишне природне середовище за період 2015-2017 pp.

\begin{tabular}{|c|c|c|c|c|c|c|c|c|}
\hline \multirow[b]{2}{*}{$\begin{array}{c}\text { № } \\
\text { Пா/ா }\end{array}$} & \multirow[b]{2}{*}{$\begin{array}{c}\text { Оціночні } \\
\text { показники }\end{array}$} & \multirow[b]{2}{*}{$\begin{array}{c}\text { Нормативні } \\
\text { значення }\end{array}$} & \multicolumn{6}{|c|}{ Фактичні звітні значення } \\
\hline & & & 2015 p. & $\begin{array}{c}\text { \% від } \\
\text { ГН на } \\
\text { рік } \\
\end{array}$ & 2016 p. & $\begin{array}{c}\% \text { від } \\
\text { ГН на } \\
\text { рік } \\
\end{array}$ & 2017 p. & $\begin{array}{c}\% \text { від } \\
\text { ГН на } \\
\text { рік } \\
\end{array}$ \\
\hline I & PB ATM & & $17,5797 \mathrm{~T}$ & $\begin{array}{c}\text { від } 10 \\
\text { до } 16 \%\end{array}$ & $19,068431 \mathrm{~T}$ & $\begin{array}{c}\text { від } \\
10,2 \text { до } \\
21,5 \% \\
\end{array}$ & $20,857543 \mathrm{~T}$ & $\begin{array}{c}\text { від } \\
11,2 \text { до } \\
24,9 \% \\
\end{array}$ \\
\hline 1.1 & Оксиди азоту & $0,5 \mathrm{мг} / \mathrm{M} 3$ & $2,6292 \mathrm{~T}$ & 15 & $2,813 \mathrm{~T}$ & 16,0 & $2,99 \mathrm{~T}$ & 17,1 \\
\hline 1.2 & \begin{tabular}{|l|} 
Викиди \\
суспендованих \\
твердих частинок \\
\end{tabular} & $0,5 \mathrm{Mr} / \mathrm{M} 3$ & $0,7792 \mathrm{~T}$ & 14 & $0,844 \mathrm{~T}$ & 15,2 & $0,93 \mathrm{~T}$ & 16,7 \\
\hline 1.3 & Оксид вуглецю & $5 \mathrm{M \Gamma} / \mathrm{M} 3$ & $11,0796 \mathrm{~T}$ & 13 & $12,05 \mathrm{~T}$ & 14,1 & $13,4 \mathrm{~T}$ & 15,7 \\
\hline 1.4 & Сірки діоксид & $0,5 \mathrm{Mr} / \mathrm{M} 3$ & $0,7273 \mathrm{~T}$ & 10 & $0,745 \mathrm{~T}$ & 10,2 & $0,811 \mathrm{~T}$ & 11,2 \\
\hline 1.5 & Бенз(а)пірени & 0,1 мкг / 100 м3 & $0,00002 \mathrm{~T}$ & 13 & $0,000025 \mathrm{~T}$ & 18,9 & $0,000033 \mathrm{~T}$ & 24,9 \\
\hline 1.6 & НМЛОС & $0,2 \mathrm{м} \Gamma / \mathrm{M} 3$ & $2,3489 \mathrm{~T}$ & 12,4 & $2,6 \mathrm{~T}$ & 13,7 & $2,7 \mathrm{~T}$ & 14,3 \\
\hline 1.7 & $\begin{array}{l}\text { Фтористий } \\
\text { водень }\end{array}$ & 0,02 мг/м3 & $0,0009 \mathrm{~T}$ & 15 & $0,00095 \mathrm{~T}$ & 15,3 & $0,00099 \mathrm{~T}$ & 15,9 \\
\hline 1.8 & \begin{tabular}{|l|}
$\begin{array}{l}\text { Залізо і його } \\
\text { сполуки }\end{array}$ \\
\end{tabular} & 0,04 мг/м3 & $0,0081 \mathrm{~T}$ & 12 & $0,0084 \mathrm{~T}$ & 12,4 & $0,0096 \mathrm{~T}$ & 14,2 \\
\hline 1.9 & ПРФ & 0,2 мг/м3 & $0,0019 \mathrm{~T}$ & 14 & $0,0022 \mathrm{~T}$ & 16,1 & $0,0027 \mathrm{~T}$ & 19,7 \\
\hline 1.10 & \begin{tabular}{|l|}
$\begin{array}{l}\text { Манган і його } \\
\text { сполуки }\end{array}$ \\
\end{tabular} & $0,001 \mathrm{мг} / \mathrm{M} 3$ & $0,0006 \mathrm{~T}$ & 16 & $0,00074 \mathrm{~T}$ & 21,5 & $0,0008 \mathrm{~T}$ & 23,2 \\
\hline 1.11 & Титану діоксид & $0,5 \mathrm{мг} / \mathrm{M} 3$ & $0,000013 \mathrm{~T}$ & 16 & $0,000016 \mathrm{~T}$ & 19,6 & $0,00002 \mathrm{~T}$ & 24,5 \\
\hline 1.12 & ЛРФ & 0,03 мг/м3 & $0,0038 \mathrm{~T}$ & 14 & $0,0041 \mathrm{~T}$ & 15,0 & $0,0052 \mathrm{~T}$ & 19,0 \\
\hline II & PA & 55 дБА & 18,5 дБА & 33,6 & 17,9 дБА & 32,5 & 16,8 дБА & 30,5 \\
\hline III & PB BP & & 0 & & 0 & & 0 & \\
\hline IV & Схема управління & відходами від ви & ироблення будів & ної прод & укції на будівель & му підпрг & иємстві & \\
\hline 4.1 & BMM, T & & 3,2 & & 3,9 & & 5,1 & \\
\hline 4.2 & ВПММ, т & & 10,1 & & 16 & & 18 & \\
\hline 4.3 & ВБМ, т & & 44 & & 47 & & 49 & \\
\hline 4.4 & ВЛ, $\mathrm{T}$ & & 5 & & 7 & & 8 & \\
\hline & Разом відходи, т & & 62,3 & & 73,9 & & 80,1 & \\
\hline $\mathrm{V}$ & $\begin{array}{l}\text { Загальний } \\
\text { висновок щодо } \\
\text { негативного } \\
\text { впливу }\end{array}$ & & $\begin{array}{l}\text { Вплив } \\
\text { знаходиться } \\
\text { на рівні нижче } \\
\text { нормативного. } \\
\text { Управління } \\
\text { відходами } \\
\text { ефективне }\end{array}$ & & \begin{tabular}{|l} 
Вплив \\
знаходиться \\
на рівні нижче \\
нормативного. \\
Управління \\
відходами \\
ефективне
\end{tabular} & & $\begin{array}{l}\text { Вплив } \\
\text { знаходиться } \\
\text { на рівні нижче } \\
\text { нормативного. } \\
\text { Управління } \\
\text { відходами } \\
\text { ефективне }\end{array}$ & \\
\hline
\end{tabular}

Джерело: розраховано за даними [5]

\section{Список літератури:}

1. Збірник показників емісії (питомих викидів) забруднюючих речовин в атмосферне повітря. URL : http://mlp.net.ua/index.php?option=com content\&task=view\&id=70\&Itemid=30 (дата звернення: 14.08.2019).

2. Компания «ЧАО «НПО «Созидатель». URL : http://sozidatel.dp.ua/rus/about/today (дата звернення: 14.08.2019).

3. Латишева О.В. Особливості екологічних стратегій сучасних промислових підприємств. URL : http://www.rusnauka.com/36_PWMN_2010/Economics/76400.doc.htm (дата звернення: 06.07.2019).

4. Светуньков М.Г., Смолькин В.П. Экологические стратегии в системе управления организацией. Вестник Самарского государственного экономического университета. 2014. № 1(111). С. 13-16.

5. Фінансовий звіт / Приватне акціонерне товариство «Металургпромжитлобуд». URL : http://mpjbud.pat.ua/ emitents/reports (дата звернення: 14.08.2019).

6. Хобта В.М., Руднєва О.Ю. Концептуальні положення регулювання екологічних наслідків діяльності підприємства. Вісник Хмельницького національного університету. 2009. № 6. Т. 3. С. 308-310. 
References:

1. Zbirnyk pokaznykiv emisii (pytomykh vykydiv) zabrudniuiuchykh rechovyn $\mathrm{v}$ atmosferne povitria [Collection of pollutants (pollutants) into the air]. Available at: http://mlp.net.ua/index.php?option=view\&i\&Itemid=30 (accessed: 14.08.2019).

2. Kompaniya AO "NPO "Sozidatel” [Company JSC NPO Sozidatel]. Available at:http://sozidatel.dp.ua/rus/about/today (accessed: 14.08.2019).

3. Latysheva, O.V. Osoblyvosti ekolohichnykh stratehii suchasnykh promyslovykh pidpryiemstv [Features of environmental strategies of modern industrial enterprises]. Available at: www.rusnauka.com/36_PWMN_2010/ Economics/76400.doc.htm (accessed: 06.07.2019)

4. Svetunkov, M.G., Smolkin, V.P. (2014). Ekologicheskie strategii v sisteme upravleniya organizatsiey [Environmental strategies in the organization management system]. Sama: Vestnik Samarskogo gosudarstvennogo ekonomicheskogo universiteta, 1(111), 13-16.

5. Finansovyi zvit Pryvatne aktsionerne tovarystvo "Metalurhpromzhytlobud" [Financial Report Metallurgpromzhitlobud, Private Joint Stock Company]. Available at: http://mpjbud.pat.ua/emitents/reports (accessed: 06.07.2019)

6. Khobta, V.M., Rudnieva, O.Iu. (2009). Kontseptualni polozhennia rehuliuvannia ekolohichnykh naslidkiv diialnosti pidpryiemstva [Conceptual provisions of regulation of environmental consequences of the enterprise]. Khmelnyts: Visnyk Khmelnytskoho natsionalnoho universytetu, 6, 308-310.

\section{ИССЛЕДОВАНИЕ НЕГАТИВНОГО ВЛИЯНИЯ СТРОИТЕЛЬНОГО ПРЕДПРИЯТИЯ НА ОКРУЖАЮЩУЮ СРЕДУ}

В статье проведено исследование, нацеленное на методическое обеспечение и практическую оценку негативного влияния исследуемых строительных предприятий Днепропетровской области на окружающую среду. Разработано авторское методическое обеспечение оценки негативного влияния исследуемых строительных предприятий на окружаюшую среду, которое предусматривает пять этапов. Научная новизна предложенной методики заключается в том, что в ней впервые на основе нормативного и сравнительного методов определено методическое обеспечение для предприятий строчтельной отрасли, тогда как в большинстве случаев оценка осуществляется в соответствии с методиками расчета определенных оценочных показателей. Руководствуясь положениями авторской методики, проведена оиенка исследуемой проблематики на примере двух субъектов строительной отрасли. Установлено, что уровень негативного влияния этих субъектов строительной отрасли на окружающую среду был ниже нормативного по основным направлениям, управление отходами было эффективным.

Ключевые слова: негативное влияние, экологизация, строительная отрасль, окружающая природная среда, выбросы, строительная продукция, нормативные данные, жилье территории.

\section{INVESTIGATION OF THE NEGATIVE IMPACT OF THE CONSTRUCTION COMPANY ON THE ENVIRONMENT}

The article deals with the methodological support and practical assessment of the negative impact of the studied construction enterprises of Dnipropetrovsk region to the environment. To achieve this goal, the following tasks were set, in particular: 1) creation of methodological support for the assessment of the negative impact of the studied construction enterprises on the environment; 2) carrying out an assessment of the negative impact of the investigated construction enterprises of Dnipropetrovsk region to the environment. The author's methodological support for the assessment of the negative impact of the investigated construction enterprises on the environment was developed, which includes five stages. The main evaluation indicators used indicators that most characterize the negative impact on the environment from the activities of construction companies. The scientific novelty of the proposed methodology is that it provides, for the first time, on the basis of regulatory and comparative methods, methodological support for construction industry enterprises, while in most cases the assessment is carried out according to the methods of calculation of certain evaluation indicators. Based on the provisions of the author's methodology, an assessment of the investigated problems was carried out on the example of five subjects of the construction industry of Dnipropetrovsk region for 2015-2017. It was found that the level of negative impact of these subjects of the construction industry on the environment was lower than the normative in the main directions, waste management was effective. It is determined that all the surveyed enterprises did not introduce innovative aspects of greening management within the framework of construction waste management. The conducted assessment of these issues allowed us to establish a picture of the negative impact of the subjects of the construction industry of Dnipropetrovsk region to the environment for 2015-2017. It is proved that the mentioned methodological support can be used for the development of methodological base of analysis, practical purposes of the study.

Key words: negative impact, greening, construction industry, environment, emissions, construction products, regulatory data, residential areas. 